Roger Williams University

DOCS@RWU

\title{
How U.S. Ocean Policy and Market Power Can Reform the Coral Reef Wildlife Trade
}

\author{
Brian N. Tissot \\ Washington State University \\ Barbara A. Best \\ Office of Natural Resources, U.S. Agency for International Development \\ Eric H. Borneman \\ University of Houston \\ Andrew W. Bruckner \\ National Marine Fisheries Service, NOAA \\ Cara H. Cooper \\ Environmental Defense Fund, 1875 Connecticut Ave., NW Washington, DC 20009, USA
}

See next page for additional authors

Follow this and additional works at: https://docs.rwu.edu/fcas_fp

Part of the Biology Commons, and the Marine Biology Commons

\section{Recommended Citation}

Tissot, B.N., B.A. Best, E.H. Borneman, A.L. Rhyne et al. 2010. "How U.S. Ocean Policy and Market Power can Reform the Coral Reef." Marine Policy 34 (36): 1385-1388.

This Article is brought to you for free and open access by the Arts and Sciences at DOCS@RWU. It has been accepted for inclusion in Arts \& Sciences Faculty Publications by an authorized administrator of DOCS@RWU. For more information, please contact mwu@rwu.edu. 


\section{Authors}

Brian N. Tissot, Barbara A. Best, Eric H. Borneman, Andrew W. Bruckner, Cara H. Cooper, Heather D'Agnes, Timothy P. Fitzgerald, Amanda Leland, Susan Lieberman, Amy Mathews Amos, Rashid Sumaila, Teresa M. Telecky, Frazer McGilvray, Brian J. Plankis, Andrew L. Rhyne, Glynnis G. Roberts, Benjamin Starkhouse, and Todd C. Stevenson 
Short Communication

\title{
How U.S. ocean policy and market power can reform the coral reef wildlife trade
}

\author{
Brian N. Tissot ${ }^{\mathrm{a}, *}$, Barbara A. Best ${ }^{\mathrm{b}}$, Eric H. Borneman ${ }^{\mathrm{c}}$, Andrew W. Bruckner ${ }^{\mathrm{d}}$, Cara H. Cooper ${ }^{\mathrm{e}}$, \\ Heather D'Agnes ${ }^{\mathrm{f}}$, Timothy P. Fitzgerald ${ }^{\mathrm{e}}$, Amanda Leland ${ }^{\mathrm{e}}$, Susan Lieberman ${ }^{\mathrm{g}}$, Amy Mathews Amos ${ }^{\mathrm{h}}$, \\ Rashid Sumaila ${ }^{\mathrm{i}}$, Teresa M. Telecky ${ }^{\mathrm{j}}$, Frazer McGilvray ${ }^{\mathrm{k}}$, Brian J. Plankis ${ }^{\mathrm{l}}$, Andrew L. Rhyne ${ }^{\mathrm{m}}$, \\ Glynnis G. Roberts ${ }^{n}$, Benjamin Starkhouse ${ }^{\mathrm{i}}$, Todd C. Stevenson ${ }^{\mathrm{a}}$ \\ a School of Earth and Environmental Science, Washington State University, 14204 NE Salmon Creek Ave., Vancouver, WA 98686, USA \\ ${ }^{\mathrm{b}}$ Office of Natural Resources, U.S. Agency for International Development, 1300 Pennsylvania Ave., NW Washington, DC 20523, USA \\ c Department of Biology and Biochemistry, University of Houston, 4800 Calhoun Rd., Houston, TX 77004, USA \\ ${ }^{\mathrm{d}}$ National Marine Fisheries Service, NOAA, 1315 East West Hwy, Silver Spring, MD 20910, USA \\ e Environmental Defense Fund, 1875 Connecticut Ave., NW Washington, DC 20009, USA \\ ${ }_{\mathrm{f}}^{\mathrm{f}}$ Public Health Institute, U.S. Agency for International Development, 1300 Pennsylvania Ave., NW Washington, DC 20523, USA \\ ${ }^{g}$ Pew Environment Group, The Pew Charitable Trusts, 901 E Street, NW Washington, DC 20004, USA \\ h Turnstone Consulting, PO Box 3283, Shepherdstown, WV 25443, USA \\ ${ }^{\mathrm{i}}$ Fisheries Centre, Aquatic Ecosystems Research Laboratory, University of British Columbia, 2202 Main Mall, Vancouver, BC Canada V6T $1 Z 4$ \\ ${ }^{\mathrm{j}}$ Humane Society International, 2100 L Street, NW Washington, DC 20037, USA \\ ${ }^{\mathrm{k}}$ Conservation International, 2011 Crystal Drive, Suite 500, Arlington, VA 22202, USA \\ ${ }^{1}$ Reef Stewardship Foundation, PO Box 841588, Pearland, TX 77584, USA \\ ${ }^{\mathrm{m}}$ Roger Williams University and New England Aquarium, RWU Department of Biology and Marine Biology, One Old Ferry Road, Bristol, RI 02809, USA \\ ${ }^{n}$ I.M. Systems Group, Inc. at the National Oceanic and Atmospheric Administration, Coral Reef Conservation Program, 1315 East West Hwy, Silver Spring, MD 20910, USA
}

\section{A R T I C L E I N F O}

\section{Article history:}

Received 14 May 2010

Accepted 5 June 2010

\section{Keywords:}

Coral reef

Marine ornamental trade

CITES

Lacey Act

Destructive fishing

Aquarium

\begin{abstract}
A B S T R A C T
As the world's largest importer of marine ornamental species for the aquaria, curio, home décor, and jewelry industries, the United States has an opportunity to leverage its considerable market power to promote more sustainable trade and reduce the effects of ornamental trade stress on coral reefs worldwide. Evidence indicates that collection of some coral reef animals for these trades has caused virtual elimination of local populations, major changes in age structure, and promotion of collection practices that destroy reef habitats. Management and enforcement of collection activities in major source countries such as Indonesia and the Philippines remain weak. Strengthening US trade laws and enforcement capabilities combined with increasing consumer and industry demand for responsible conservation can create strong incentives for improving management in source countries. This is particularly important in light of the March 2010 failure of the parties to the Convention on International Trade in Endangered Species (CITES) to take action on key groups of corals.
\end{abstract}

(c) 2010 Elsevier Ltd. All rights reserved.

\section{Introduction}

The United States is the world's largest importer of marine ornamental species for the aquarium, curio, home décor, and jewelry industries, importing more than $50-60 \%$ of live coral, coral reef fish and invertebrates in trade [1,2] (Fig. 1). These widespread and growing trades add to the cumulative stresses that coral reefs are facing from climate change, ocean acidification, overfishing, destructive fishing and land based pollution. Unfortunately, the recent meeting of the Convention

\footnotetext{
* Corresponding author. Tel.: +1 360546 9611; fax: +1 3605469064 .

E-mail address: tissot@vancouver.wsu.edu (B.N. Tissot).
}

on International Trade in Endangered Species of Wild Fauna and Flora (CITES) in March 2010 once again failed to take action to regulate trade in red and pink precious corals threatened by trade activities. This rejection by the CITES member governments highlights the urgent need for other action. As the world's largest consumer of marine ornamental species, the U.S. has an opportunity to leverage its considerable market power to promote more sustainable trade and reduce the effects of ornamental trade stress on coral reefs worldwide.

More than 40 scientists, government officials, industry leaders, and representatives from conservation and animal protection organizations met in May 2009 in Washington DC to explore the current state of knowledge of the trade in coral and coral reef species for ornamental purposes, and discuss actions that could be 
taken in the U.S. to promote a more responsible, sustainable and humane trade. Strengthening U.S. laws and enforcement capabilities combined with increasing consumer and industry demand for more responsible practices can create incentives for improved management in source countries and reduce the ecological impacts of U.S. consumption in traded species.

\section{Volume of trade}

Existing data indicate that the diversity and volume of species traded is substantial and growing. Trade in coral and coral reef species originates from at least 45 countries, and removes up to 30 million fish, 1.5 million live stony corals, over 2 million kilograms of dead coral, 30-50 metric tons of red and black coral and over 2500 metric tons of shells per year from coral reefs [1,3-6]. The global trade in marine ornamentals for aquaria alone targets over 1500 species of reef fishes, 500 species of invertebrates, hundreds of coral species, as well as live rock [7]. Between

\section{a}

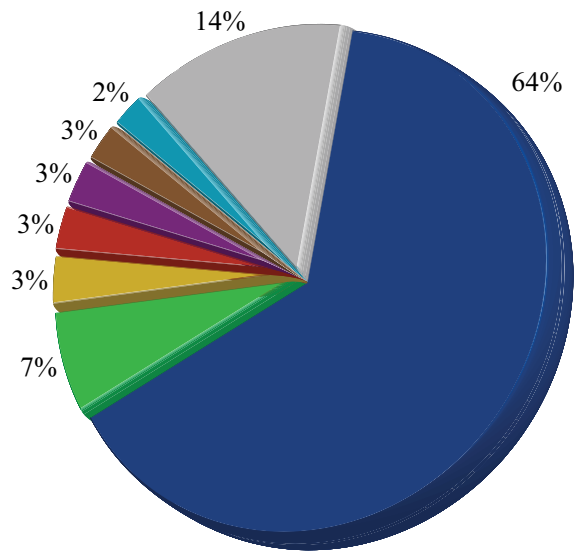

US
Japan
Italy
Netherlands
Canada
United Kingdom
France
Remaining 95
countries

b

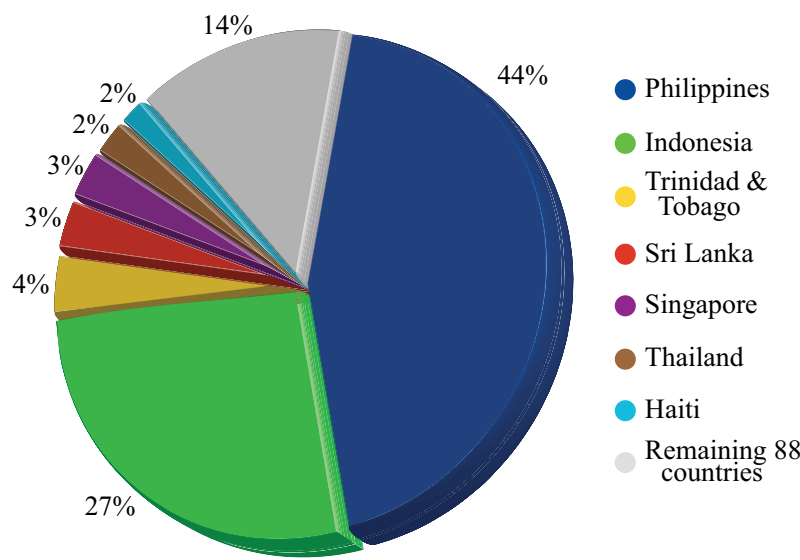

Fig. 1. (a) Coral imports worldwide, by importing country. Data obtained from the UNEP-WCMC CITES Trade Database [8] for trade in CITES-listed species of coral 2004-2008 demonstrates that the U.S. imports $64 \%$ of the total coral species in numbers of specimens. The vast majority originated in the Coral Triangle region, with Indonesia having exported over $60 \%$ of the corals. This chart does not include coral jewelry and other worked coral products, which have different units of measurement in the database. Nonetheless, the data show that the U.S. is also the leading importer of these products. (b) U.S. imports of marine tropical fish, by exporting country. Data obtained from the U.S. Fish and Wildlife Service for the U.S. importation of live marine tropical fish (2004-2008) show that $71 \%$ of the trade originated in just two countries in the Coral Triangle, the Philippines and Indonesia. It is worth noting that these data were taken at face value and are dependent on the accuracy of the reported type and volume of items in trade.
1988 and 2007, the imports of live corals taken directly from reefs to the U.S. has increased $600 \%$, while the global volume of live coral imports increased nearly $1500 \%$ [8].

\section{Ecological impacts}

Trade in some species has caused the virtual elimination of local populations, major changes in age structure, and promotion of collection practices that destroy reef habitats [9-12]. For example, populations of the Banggai cardinalfish (Pterapogon kaudneri), an endemic species from a remote archipelago in Sulawesi, Indonesia, have been substantially reduced or eliminated throughout much of the species' range since its popularity for marine aquaria soared in the late 1990s [13]. Long recognized as the "shell capital of the world," the Philippines have experienced boom and bust cycles from overfishing and many once abundant mollusks have become commercially extinct due to overharvesting for the curio trades [3]. Precious and semiprecious corals (i.e. black and red corals) used for jewelry and home decorations have been overfished as collectors deplete certain areas and animals, then move on to other geographic areas, deeper waters, and other species [14].

Species taken for the live aquarium trade are extremely perishable, increasing the potential for overexploitation as collectors gather additional live animals from the reef to compensate for the high mortality that can occur during holding and transport [15]. The live aquarium trade is also a pathway for invasive and non-native species into the U.S. that can cause significant impacts to local and regional biodiversity $[16,17]$. For example, introduction of the Indo-Pacific Lionfish (Pterois volitans) into U.S. Atlantic waters was very likely from an aquarium [18], and they have spread rapidly northward along the eastern seaboard of the U.S. and southward throughout the Caribbean causing severe impacts to local fish populations [19].

\section{Management and regulation}

Management and regulation of species collected for the marine ornamental trades are not sufficiently developed in most countries. Weak local and national governance capacity in major source countries, such as in Indonesia and the Philippines, combined with high international demand have resulted in limited and ineffective management. 'Roving collectors' that move throughout the region and within countries in search of higher value species collect a substantial portion of marine aquarium fish and can undermine local management efforts $[20,21]$. Inadequate enforcement of the few existing laws allows collectors to utilize illegal and destructive collection methods, such as sodium cyanide to collect fish, that have negative impacts for the health of non-target species and collectors [22,23].

\section{Recommended action}

With continuing high demand from the United States, many source countries have few incentives to improve management practices or strengthen trade policies. Strengthening U.S. laws and enforcement capabilities combined with increasing consumer and industry demand for more responsible products can create strong incentives for improving resource management in source countries. Workshop participants identified four key areas in which U.S. actions could influence trade practices. 


\subsection{Reform U.S. laws and regulations on the trade}

Currently, US legal and regulatory tools governing the import of coral and coral reef species are limited. The primary tools to regulate trade into the U.S. include the Convention on International Trade in Endangered Species of Wild Fauna and Flora (CITES), the Endangered Species Act (which implements CITES in the U.S.), and the Lacey Act. Although CITES requires that international trade of species included in Appendix II is regulated so that collection is not detrimental to species survival or its role in the ecosystem, only a few groups of the thousands of coral reef species in the marine ornamental trades are currently listed. In the meantime, many thousands of other species traded will remain unexamined and unlisted, exacerbated by limited management in source countries. In 2007, and again in March 2010, efforts to list red and pink corals under Appendix II of CITES failed, despite clear evidence of the need for increased protection, highlighting the limitations of relying solely on CITES as a policy tool. The Lacey Act prohibits wildlife imports that were obtained in violation of foreign laws. While the import of animals taken with illegal collection practices such as cyanide is clearly a violation, the U.S. lacks internationally recognized cyanide detection tests to collect evidence needed for enforcement [22]. The Lacey Act also allows the U.S. to list and ban injurious species and provides for the humane and healthful transport of live animals into the United States. However, explicitly listing species as injurious is a cumbersome and time-consuming process. Without listing, the Act cannot be applied. Moreover, there are currently no mandatory or enforced regulations in place for humane and healthful transport of fish and invertebrates.

Additional tools are needed to address these legal and regulatory gaps and ensure that the U.S. is not importing coral reef species (or their products) collected through poorly managed, unsustainable, or destructive practices. The current challenge will be constructing a new trade policy for coral reef species that addresses both negative impacts to the reef resources and promotes the development of sustainable and humane alternative products to supply a growing global demand.

\subsection{Improve enforcement}

The U.S. Fish and Wildlife Service is tasked with inspecting shipments of wildlife imported into the country to ensure that they comply with the law. The overwhelming number of shipments and animals, as well as the challenges of properly identifying taxa, make enforcement difficult [24]. Additional resources, training, and better tracking systems are needed to improve trade data and adequately address the problem. Mortality of live animals in trade could also be reduced by improving and enforcing the voluntary Live Animal Transport Regulations of the International Air Transport Association used for humane transport of live animals.

\subsection{Shift market demand to sustainable products}

Changing U.S. market demand for poorly managed coral reef species to those acquired by more sustainable practices can shift market incentives. Over the last decade, there have been voluntary efforts to improve practices in the marine aquarium trade, including efforts to better track trade, improve standards of care, develop breeding and mariculture initiatives, and propagate corals for trade.

Although there have been major efforts towards voluntary certification of the live animal trade for aquarium fish, truly shifting U.S. market demand will require substantial consumer education, engagement and proactive leadership by responsible businesses, combined with policy reform. Businesses can work with environmental nongovernmental organizations to facilitate access to more sustainable and humane sources and identify best practices to reduce mortality of collected animals. Licensing requirements for importers, wholesalers, and retailers could improve recordkeeping and husbandry practices and create a barrier to entry for the worst players where mortality is highest.

\subsection{Promote reform and best practices in source countries}

Ultimately, real change must occur in source countries. All countries in which coral and coral reef organisms are collected including parts of the U.S. - should maintain high standards for conserving coral reef ecosystems in their practice of trade. Regional and U.S. investments in conservation efforts in the Coral Triangle region, a major source of the ornamental trade, could help address fundamental management problems. High demand in the U.S. for coral reef products creates perverse economic incentives that can undermine efforts to strengthen their management. Therefore, efforts to promote ecosystem-based management in source countries should be paired with U.S. action to influence trade for sustainable use of these resources.

\section{Conclusion}

In light of the continued failure of CITES, it is clear that other approaches are necessary to conserve vulnerable marine ornamental species. Collection of these animals can have significant negative impacts on already stressed ecosystems and undermine local management efforts. The U.S. should assume its role as an international leader in coral reef conservation and take steps to reform the international trade it drives.

\section{Acknowledgements}

The authors thank the Kingfisher Foundation for its support of the International Trade in Coral Reef species workshop, and other workshop participants, including Sheila Einsweiler, Lisa Nichols, Chris Buerner, Patricia DeAngelis, Candice Dorsey, Todd Dubois, Mike Dunmyer, Rosemarie Gnam, Dave Gulko, Andy Hooten, Craig Hoover, Jeremy Jackson, Kevin Kohen, Jeremy Linneman, Kelly Milton, Laura Noguchi, Julia Roberson, Emily Tibbott, and Sue Wells. We thank Nancy Baron for her helpful comments on the manuscript. The views expressed here reflect those of the authors, and do not necessarily reflect the views of their institutions.

\section{References}

[1] Bruckner AW. The importance of the marine ornamental reef fish trade in the wider Caribbean. Revista Biologica Tropical 2005;53:127-38.

[2] Bruckner AW. Proceedings of the international workshop on the trade in stony corals: development of sustainable management guidelines. U.S. Department of Commerce NOAA Technical Memorandum 2002; NMFS-OPR-23 $<$ http://www.nmfs.noaa.gov/habitat/ead/ecosysdocs/indonesiaproceedingsfinal. pdf $>$.

[3] Floren AD. The Philippine shell industry with special focus on Mactan Cebu. U.S. Agency for International Development; 2003. <http://www.oneocean. org/download/db_files/philippine_shell_industry.pdf $\rangle$.

[4] Grey M, Blais AM, Vincent ACJ. Magnitude and trends of marine fish curio imports to the USA. Oryx 2005;39:413-20.

[5] Rhyne A, Rotjan R, Bruckner AW, Tlusty M. Crawling to collapse: ecologically unsound ornamental invertebrate fisheries. PLoS One 2009:e8413, doi:10.1371/journal.pone.0008413.

[6] Wood EM. Collection of coral reef fish for aquaria: global trade, conservation issues and management strategies. Marine Conservation Society, Herefordshire, UK: MCS; 2001. 
[7] Wabnitz C, Taylor M, Green E, Razak T. From ocean to aquarium. UNEP World Conservation Monitoring Centre, Cambridge, UK: UNEP-WCMC; 2003 $\langle$ http://www.unep-wcmc.org/resources/PDFs/WCMC_Aquarium.pdf $\rangle$.

[8] CITES Database; January 2010 〈http://www.unep-wcmc.org/citestrade/in dex.cfm $>$.

[9] Kolm N, Berglund A. Wild populations of a reef fish suffer from the "nondestructive" aquarium trade fishery. Conservation Biology 2003;17: 910-4.

[10] Marcus JE, Samoilys MA, Meeuwig JJ, Villongco ZAD, Vincent ACJ. Benthic status of near-shore fishing grounds in the central Philippines and associated seahorse densities. Marine Pollution Bulletin 2007;54:1483-94.

[11] Shuman CS, Hodgson G, Ambrose RF. Population impacts of collecting sea anemones and anemonefish for the marine aquarium trade in the Philippines. Coral Reefs 2005:564-73.

[12] Tissot BN, Hallacher LE. Effects of aquarium collectors on coral reef fishes in Kona, Hawaii. Conservation Biology 2003;17:1759-68.

[13] Vagelli AA, Erdmann MV. First comprehensive ecological survey of the Banggai cardinalfish Pteropogon kauderni. Environmental Biology of Fishes 2002;63:1-8.

[14] Tsounis G, Rossi S, Grigg R, Santangelo G, Bramanti L, Gili JP. The exploitation and conservation of precious corals. Oceanography and Marine Biology Annual Review 2010;48:161-212.

[15] Rubec PJ, PrattV Cruz Fm, Oellers R, McCullough B, Lallo F. Cyanide-free netcaught fish for the marine aquarium trade. Aquarium Sciences and Conservation 2001;3:37-51.

[16] Semmens BX, Buhle ER, Salomon AK, Pattengill-Semmens CV. A hotspot of non-native marine fishes: evidence for the aquarium trade as an invasion pathway. Marine Ecology Progress Series 2004;266:239-44.
[17] Smith KF, Behrens M, Schloegel LM, Marano N, Burgiel S, Daszak P. Reducing the risks of the wildlife trade. Science 2009;324:594-5.

[18] Whitfield PE, Gardner T, Vives SP, Gilligan MR, Courtenay Jr. WR, Ray GC, et al. Biological invasion of the Indo-Pacific lionfish Pterois volitans along the Atlantic coast of North America. Marine Ecology Progress Series 2002;235:289-97.

[19] Albins MA, Hixon MA. Invasive Indo-Pacific lionfish Pterois volitans reduce recruitment of Atlantic coral-reef fishes. Marine Ecology Progress Series 2008;367:233-8.

[20] Berkes F, Hughes TP, Steneck RS, Wilson JA, Bellwood DR, Crona B, et al. Ecology: globalization, roving bandits, and marine resources. Science 2006;311:1557-8.

[21] Marine Aquarium Market Transformation Initiative. Report on roving collectors: case studies from Indonesia and the Philippines. Marine Aquarium Council, Reef Check, and Conservation and Community Investment Forum: MAMTI Technical Report; 2006. 〈http://www.aquariumcouncil.org/materi als/Roving-Collectors-Report-Final.pdf $\rangle$.

[22] Bruckner AW, Roberts G Proceedings of the international cyanide detection testing workshop. U.S. Department of Commerce NOAA Technical Memorandum 2008; NMFS-OPR-40〈http://www.nmfs.noaa.gov/pr/pdfs/nmfsopr40. pdf $>$.

[23] Jones RJ, Hoegh-Guldberg O. Effects of cyanide on coral photosynthesis: implications for identifying the cause of coral bleaching and for assessing the environmental effects of cyanide fishing. Marine Ecology Progress Series 1999;177:83-91.

[24] Smith KF, Behrens MD, Max LM, Daszak P. U.S. drowning in unidentified fishes: scope, implications, and regulation of live fish import. Conservation Letters 2008;1:103-9. 